\title{
Analisis Sikap Multiatribut Fishbein Dalam Pengambilan Keputusan Mahasiswa Memilih Kampus IBI Kesatuan
}

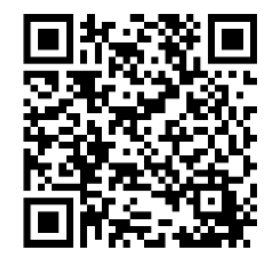

\author{
Febry Lodwyk Rihe Riwoe ${ }^{1}$, Jan Horas Veryady Purba², Gen Gen Gendalasari3 \\ DOI: https://doi.org/10.36339/jaspt.v5i1.409
}

\begin{abstract}
Abstrak
Penelitian ini bertujuan untuk menganalisis keputusan calon mahasiswa dalam memutuskan pemilihan Perguruan Tinggi di Institut Bisnis dan Informatika Kesatuan, Model analisis yang digunakan adalah Analisis sikap Multiatribut Fishbein. Terdapat 10 aribut yang dianalisis, yakni (1) kualitas akreditasi, (2) fasilitas, (3) kualitas dosen, (4) biaya kuliah, (5) lokasi, (6) faktor teman/keluarga, (7) suasana kampus, (8) beasiswa, (9) pelayanan dan (10) mudah bekerja. Analisis sikap mahasiswa dilihat dari dua variabel yakni tingkat kepercayaan (belief) mahasiswa atas atribut Perguruan Tinggi dan evaluasi mahasiswa atas atribut tersebut dan sekaligus mengukur score kinerjanya. Teknisk pengambilan sampel adalah proportional random sampling, dengan sampel 288 responden dari populasi 1025 orang mahasiswa. Berdasarkan nilai kepercayaan sikap mahasiswa terhadap pemilihan perguruan tinggi di Kota Bogor diperoleh rata-rata score dengan nilai 3.841, dan berada pada kategori baik, sedangkan nilai evaluasi sikap mahasiswa terhadap perguruan tinggi IBI Kesatuan diperoleh rata-rata score 4.009 berada pada kategori baik. Terdapat dua atribut yang paling tinggi dan masuk dalam kategori sangat penting, yakni Mudah bekerja (4.316) dan Kualitas Akreditasi (4.313), dan Akreditasi yang mencerminkan kualitas IBI Kesatuan. Nilai sikap dengan model Fishbein dalam pemilihan Perguruan Tinggi IBI Kesatuan didapat score sikap sebesar 159,94 berada pada interval "baik".
\end{abstract}

Kata Kunci: Fishbein, Belief, Evaluation, Performance, Importance.

\section{PENDAHULUAN}

Pendidikan merupakan salah satu bagian penting dalam Pembangunan Sumber Daya Manusia di Indonesia. Setelah lulus dari SMA atau SMK, para siswa memiliki 3 pilihan, yakni melanjutkan kuliah, menunda kuliah, atau bekerja. Sebagian besar para lulusan mempunyai harapan dapat melanjutkan dan menyelesaikan pendidikannya hingga ke jenjang yang lebih tinggi. Para siswa dihadapkan pada pemilihan Program Studi serta Kampus tempat kuliah. Tujuan penelitian ini adalah untuk mengetahui faktor-faktor yang mempengaruhi keputusan para alumni SMA, MA dan SMK di Kota Bogor dalam memilih Institut Bisnis dan Informatika Kesatuan, Bogor. Mengetahui minat atau keinginan calon mahasiswa untuk melanjutkan Pendidikan sangatlah penting bagi kampus, namun untuk mengetahui minat-minat yang diinginkan oleh calon mahasiswa menjadi suatu permasalahan utama bagi kampus dalam membuka Program Studi dan memasarkannya. Minat calon mahasiswa untuk melanjutkan pendidikan memiliki cara pandangan yang berbeda-beda dalam mengambil pilihan perguruan Tinggi yang

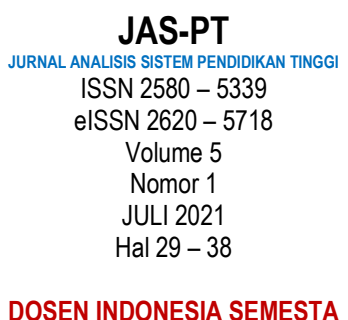

DOSEN INDONESIA SEMESTA
Program Studi Manajemen Fakultas Bisnis, Institut Bisnis dan Informatika Kesatuan

Program Studi Manajemen, Fakultas Bisnis, Institut Bisnis dan Informatika Kesatuan. Jalan

Ranggagading No. 1 Bogor 16123 West Java, Indonesia

Email of Corresponding Author : mr.febry@ibik.ac.id

Submitted November 2020

Accepted Maret 2021 
diingikan dengan mengetahui kelemahan dan keunggulan yang dimiliki oleh setiap kampus yang pada akhirnya dapat meningkatkan kualitas produk dan pelayanannya sehingga dapat menarik calon mahasiswa.

Agar kampus dapat minat calon mahasiswa terhadap program studi yang ditawarkan maka kampus dapat menggunakan quisioner pengamatan mengenai prodi yang ditawarkan, sehingga produsen dapat mengetahui kelemahan dan mempertahankan maupun meningkatkan keunggulan yang dimiliki.

Perkembangan zaman saat ini memberikan pengaruh yang luar biasa terhadap kehidupan, diantaranya kebutuhan atas sumber daya manusia terus meningkat. Di era Revolusi Industri 4.0 saat ini, yang merupakan sebuah revolusi industri keempat, memberikan efek besar kepada ekosistem dunia dan tata cara kehidupan. Revolusi industri 4.0 bahkan diyakini dapat meningkatkan perekonomian dan kualitas kehidupan secara signifikan. Revolusi Industri 4.0 menerapkan konsep automatisasi yang dilakukan oleh mesin tanpa memerlukan tenaga manusia dalam pengaplikasiannya.

Hal tersebut tentu menjadi sebuah tantangan besar bagi semua perguruan tinggi (PT) di Indonesia untuk terus mengembangkan program studi yang mereka miliki, agar menghasilkan SDM yang berkualitas. Kualitas lulusan menjadi penentu utama keberlangsungan hidup suatu perguruan tinggi. Perguruan tinggi dikatakan berkualitas, apabila telah mampu menghasilkan lulusan yang memenuhi kompetensi. Bila sebuah perguruan tinggi menghasilkan lulusan yang banyak menganggur, maka perguruan tinggi itu lambat laun akan ditinggalkan oleh masyarakat. Secara umum, persaingan antara perguruan tinggi di wilayah Bogor tidak saja hanya untuk program studi yang sejenis, namun juga antara program studi yang berbeda, karena pada hakikatnya calon mahasiswa memiliki banyak pilihan sebelum memutuskan untuk memilih salah satu program studi. Berbeda kondisinya jika calon mahasiswa sudah memiliki pilihan sejak awal dan bertekad untuk masuk di program studi pilihannya tersebut.

Kehadiran mahasiswa baru setiap tahun akademiknya diperlukan oleh setiap PTS untuk kelangsungan hidup PTS tersebut. Kelangsungan hidup penyelengaraan PTS sangat ditentukan oleh keberhasilan mereka mendapatkan mahasiswa baru pada setiap tahun akademiknya. Persaingan di antara PTS berat sehingga diperlukan strategi pemasaran yang baik, oleh karena itu, komunikasi pemasaran yang dilakukan oleh PTS yang dapat membuat calon mahasiswa memutuskan untuk memilih PTS tersebut sebagai tempat mereka melanjutkan studi, menjadi sangat penting diketahui oleh PTS.

Keputusan calon mahasiswa sebagai konsumen dipengaruhi banyak faktor diantaranya adalah usaha pemasaran dan faktor lainnya seperti faktor sosial atau kelompok acuan (Kotler K. , 2009). Calon mahasiswa sebagai prospek bagi perguruan tinggi dalam menentukan pilihannya dipengaruhi oleh faktor internal dirinya sebagai konsumen sendiri, produk atau jasa yang ditawarkan dan dari pihak produsen dalam hal ini PTS dalam mengkomunikasikan produknya kepada calon mahasiswa. Komunikasi oleh PTS dilaksanakan dalam aktivitas promosi. Griffin dan Ebert (Somad \& Doni, 2014) menyatakan bahwa promosi merupakan teknik apapun yang dirancang untuk menjual suatu produk, jasa. Salah satu perguruan tinggi di Kota Bogor adalah Insitut Bisnis dan

JAS-PT

JURNAL ANALISIS SISTEM PENDIDIKAN TINGGI

ISSN $2580-5339$

eISSN $2620-5718$

Volume 5

Nomor 1

JULI 2021

Hal 39 - 48

DOSEN INDONESIA SEMESTA
Informatika Kesatuan (IBIK). Institut Bisnis dan Informatika Kesatuan (IBIK) berharap di masa yang akan datang menjadi perguruan tinggi yang mampu menciptakan lulusan yang memiliki akhlak baik dan kemampuan intelektual yang kuat, melalui pengembangan pendidikan karakter. IBIK juga menghadapi persaingan yang tidak mudah dalam mendapatkan mahasiswa baru pada setiap tahun akademiknya. IBIK memiliki unit Marketing/Pemasaran yang secara teknis dilakukan untuk pelaksanaan promosi dan rekrutmen mahasiswa. Kegiatan komunikasi pemasaran berperan penting dan penentu 
sukses tidaknya pemasaran, dengan kegiatan ini diharapkan kesadaran merek di benak konsumen juga tercipta. Iklan penerimaan mahasiswa baru di surat kabar, radio, media online, selebaran cetak, brosur, baliho dan spanduk di jalan maupun di dalam kampus dilaksanakan guna menjaring mahasiswa baru. Jumlah mahasiswa baru yang mengalami fluktuasi dari tahun 2015 sampai dengan 2019. Jumlah mahasiswa baru IBIK sempat mengalami kenaikan pada tahun 2017 mencapai 987 mahasiswa, menurun pada tahun 2018 menjadi 813 mahasiswa, tetapi kembali naik pada tahun 2019 menjadi 1056 mahasiswa. dan kembali naik pada tahun 2020 menjadi 1074 mahasiswa.

Hal di atas dapat menunjukkan bahwa banyak artibut yang mempengaruhi mahasiswa memilih perguruan Tinggi untuk melanjutkan pendidikan Tinggi dipengaruhi oleh banyak Faktor yang digambarkan oleh jumlah penerimaan mahasiswa baru yang menjadi tolak ukur daripada minat studi pada IBI Kesatuan Bogor. Oleh karena itu, berdasarkan latar belakang masalah di atas, penulis tertarik untuk melakukan penelitian dengan judul : "Analisis Sikap Multiatribut Fishbein dalam Pengambilan Keputusan Mahasiswa memilih Kampus Institut Bisnis dan Informatika Kesatuan".

\section{METODE PENELITIAN}

Jenis Penelitian adalah penelitian deskriptif. Penelitian deskriptif adalah jenis penelitian yang menggambarkan apa yang dilakukan oleh perusahaan berdasarkan fakta-fakta yang ada berkaitan dengan penelitian ini untuk selanjutnya diolah menjadi data. Metode yang digunakan dalam penelitian ini yaitu metode kuantitatif. Metode kuantitatif dapat diartikan sebagai metode penelitian yang berlandaskan pada filsafat positivisme digunakan untuk meneliti pada populasi atau sampel tertentu, pengumpulan data menggunakan instrument penelitian, analisis data bersifat kuantitatif (Sugiyono 2014, p.13). Penelitian ini bertujuan untuk menganalisis Sikap Multiatribut Fishbein dalam Pengambilan Keputusan Mahasiswa memilih Kampus IBI Kesatuan. Model Fishbein memiliki dua komponen (Umar, 2005: 59), yaitu berikut ini.

1. Komponen sikap. Komponen ini bersifat internal individu, berkaitan langsung dengan objek penelitian dan atribut-atribut langsungnya yang memiliki peranan penting dalam ukuran perilaku karena akan menentukan tindakan apa yang akan dilakukan, dengan tidak dipengaruhi faktor eksternal.

2. Komponen norma subjekti. Komponen ini bersifat eksternal individu yang berpengaruh terhadap perilaku individu. Komponen ini dapat dihitung dengan cara mengalikan antara nilai keyakinan normatif individu terhadap atribut dengan motivasi bersetuju ter- hadap atribut tersebut.

Model multiatribut fishbein digambarkan dengan formula berikut:

$$
\text { Ao }=\sum_{i=1}^{N} b i \cdot e i
$$

Keterangan:

Ao $=$ Sikap terhadap suatu objek

bi $=$ Kekuatan kepercayaan bahwa objek tersebut memiliki atribut $\mathrm{i}$

ei $=$ evaluasi terhadap atribut $\mathrm{I}$

$\mathrm{N}=$ jumlah atribut yang dimiliki objek

Model ini secara singkat menyatakan sikap seorang konsumen terhadap suatu objek akan ditentukan sikapnya terhadap berbagai atribut yang dimiliki objek tersebut. Komponen ei mengukur evaluasi kepentingan atribut yang dimiliki oleh objek tersebut. Konsumen belum memperhatikan merek suatu produk ketika mengevaluasi tingkat

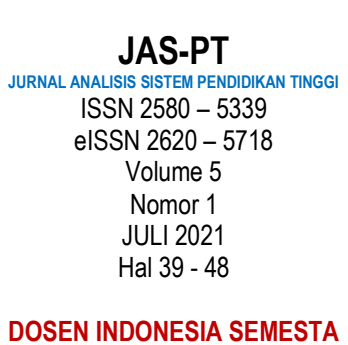

JAS-PT

ISSN $2580-5339$

Volume 5

Nomor 1

JULI 2021

DOSEN INDONESIA SEMESTA 
kepentingan atribut tersebut. Untuk menentukan sampel dalam penelitian ini mengunakan teknik Solvin dengan margin error $5 \%$. Dengan populasi calon mahasiswa sebanyak 1025 orang, maka jumlah sampel adalah sebagai berikut :

$$
n=\frac{1025}{1+1025\left(00,5^{2}\right)}=287,7
$$

Dengan demikian Responden penelitian ini adalah 288 orang. Pada tahap pengumpulan data, jawaban responden yang sahih dan lengkap adalah 256 orang, sehingga Penelitian ini menggunakan data responden sebanyak 256 orang.

Untuk menentukan interval skala sikap, digunakan formula berikut :

Dimana :

$$
i=\frac{a *(m-n)}{b}
$$

$$
\begin{array}{ll}
\mathrm{i} & =\text { interval } \\
\mathrm{a} & =\text { jumlah atribut } \\
\mathrm{b} & =\text { jumlah skala penilaian yang mungkin terjadi Skala interval } \\
\mathrm{m} & =\text { skor tertinggi yang mungkin terjadi } \\
\mathrm{n} & =\text { skor terendah yang mungkin terjadi }
\end{array}
$$

Dengan formula atas, dapat disusu skala interval sikap sebagai berikut:

Tabel 1. Skala Interval Sikap Mahasiswa dalam Memilih IBIK

\begin{tabular}{cl}
\hline Skala & \multicolumn{1}{c}{ Nilai Sikap } \\
\hline $10 \leq$ Ao $\leq 58$ & Sangat Buruk \\
$58.1 \leq$ Ao $\leq 106$ & Buruk \\
$106.1 \leq$ Ao $\leq 154$ & Biasa \\
$154.1 \leq$ Ao $\leq 202$ & Baik \\
$202.1 \leq$ Ao $\leq 250$ & Sangat Baik \\
\hline
\end{tabular}

\section{HASIL DAN PEMBAHASAN}

\section{a. Kategori Kepercayaan (bi)}

Tabel 2. Hasil Jawaban Responden Mengenai sikap Mahasiswa diukur dengan Konsep Kepercayaan (bi)

JAS-PT

JURNAL ANALISIS SISTEM PENDIDIKAN TINGGI ISSN $2580-5339$

\begin{tabular}{|c|c|c|c|c|c|c|c|c|c|c|c|}
\hline \multirow{3}{*}{ No } & \multirow{3}{*}{ Pernyataan } & \multicolumn{10}{|c|}{ Jawaban } \\
\hline & & \multicolumn{2}{|c|}{ SS } & \multicolumn{2}{|c|}{$\mathrm{S}$} & \multicolumn{2}{|c|}{$B$} & \multicolumn{2}{|c|}{ TS } & \multicolumn{2}{|c|}{ STS } \\
\hline & & $\mathrm{F}$ & $\%$ & $f$ & $\%$ & $f$ & $\%$ & $f$ & $\%$ & $f$ & $\%$ \\
\hline 1 & Kualitas Akreditasi & 79 & 30.9 & 148 & 57.8 & 26 & 10.2 & 1 & 0.4 & 2 & 0.8 \\
\hline 2 & & 5 & 21.9 & 156 & 60.9 & 38 & 14.8 & 6 & 2.3 & 0 & \\
\hline & & 45 & 17.6 & 147 & 57.4 & 57 & 22.3 & 4 & 1.6 & 3 & 1.2 \\
\hline 2 & Biay & 63 & 24.6 & 115 & 44.9 & 62 & 24.2 & 13 & 5.1 & 3 & 1.2 \\
\hline 5 & Loka & 109 & 42.6 & 110 & 43.0 & 31 & 12.1 & 5 & 2.0 & 1 & 0.4 \\
\hline & & 40 & 15.6 & 89 & 34.8 & 65 & 25.4 & 46 & 18.0 & 16 & 6.3 \\
\hline & Suas & 25 & 9.8 & 122 & 47.7 & 94 & 36.7 & 14 & 5.5 & 1 & 0.4 \\
\hline$\varepsilon$ & Beasi & 65 & 25.4 & 39 & 15.2 & 39 & 15.2 & 69 & 27.0 & 44 & 17.2 \\
\hline & & 71 & 27.7 & 138 & 53.9 & 42 & 16.4 & 5 & 2.0 & 0 & \\
\hline 10 & M & 76 & 29.7 & 139 & 54.3 & 36 & 14.1 & 4 & 1.6 & 1 & 0.4 \\
\hline & ta-r & 62.9 & 24.6 & 120.3 & 47.0 & 49 & 19.1 & 16.7 & 6.5 & 7.1 & 2.8 \\
\hline
\end{tabular}
eISSN $2620-5718$

Volume 5

Nomor 1

JULI 2021

Hal 39 - 48

DOSEN INDONESIA SEMESTA

Sumber : Data diolah (2020) 
Dari tabel 2 diperoleh jawaban atas beberapa pernyataan yang diajukan ke 256 responden, pernyataan ke-5 mengenai "lokasi kampus" mendapat respon tertinggi dengan jawaban sangat setuju yaitu sebanyak 109 orang atau 42,6\%. Sedangkan pernyataan 7 mengenai "Suasana Kampus" mendapat respon terendah dengan jawaban sangat setuju sebanyak 25 orang atau $9,8 \%$.

\section{b. Kategori Evaluasi (ei)}

Tabel 3. Hasil Jawaban Responden Mengenai sikap Mahasiswa diukur dengan Konsep Evaluasi (ei)

\begin{tabular}{|c|c|c|c|c|c|c|c|c|c|c|c|}
\hline \multirow{3}{*}{ No } & \multirow{3}{*}{ Pernyataan } & \multicolumn{10}{|c|}{ Jawaban } \\
\hline & & \multicolumn{2}{|c|}{ SS } & \multicolumn{2}{|c|}{$S$} & \multicolumn{2}{|c|}{$B$} & \multicolumn{2}{|c|}{ TS } & \multicolumn{2}{|c|}{ STS } \\
\hline & & $F$ & $\%$ & $f$ & $\%$ & $f$ & $\%$ & $f$ & $\%$ & $f$ & $\%$ \\
\hline 1 & Kualitas Akreditasi & 115 & 44.9 & 112 & 43.8 & 25 & 9.8 & 2 & 0.8 & 2 & 0.8 \\
\hline 2 & Fasili & 91 & 35 & 124 & 48.4 & 35 & 13 & & 1.6 & 2 & 0.8 \\
\hline 3 & Kualitas Dosen, & 89 & 34.8 & 120 & 46.9 & 41 & 16.0 & 2 & 0.8 & 4 & 1.6 \\
\hline 4 & Biaya Kuli & 81 & 31.6 & 108 & 42.2 & 57 & 22.3 & 9 & 3.5 & 1 & 0. \\
\hline 5 & Lokasi & 103 & 40.2 & 105 & 41.0 & 44 & 17.2 & 4 & 1.6 & 0 & \\
\hline 6 & $\begin{array}{l}\text { Faktor } \\
\text { Teman/Keluarga }\end{array}$ & 35 & 13.7 & 81 & 31.6 & 82 & 32.0 & 44 & 17.2 & 14 & \\
\hline 7 & Suas & 68 & 26.6 & 135 & 52.7 & 48 & 18.8 & 4 & 1.6 & 1 & 0. \\
\hline 8 & Beasisv & 66 & 25.8 & 66 & 25.8 & 63 & 24.6 & 40 & 15.6 & 21 & 8.2 \\
\hline 9 & Pelayanan & 85 & 33.2 & 130 & 50.8 & 39 & 15.2 & 1 & 0.4 & 1 & 0.4 \\
\hline 10 & Mudah b & 118 & 46.1 & 104 & 40.6 & 32 & 12.5 & 1 & 0.4 & 1 & 0.4 \\
\hline & Rata-rata & 85.1 & 33.2 & 108.5 & 42.4 & 46.6 & 18.2 & 11.1 & 4.3 & 4.7 & 1. \\
\hline
\end{tabular}

Dari tabel 3 diperoleh jawaban atas beberapa pernyataan yang diajukan ke 256 responden, pernyataan ke-5 mengenai "lokasi kampus" mendapat respon tertinggi dengan jawaban sangat setuju yaitu sebanyak 103 orang atau 40,2\%. Sedangkan pernyataan 6 mengenai "Faktor Teman atau Keluarga" mendapat respon terendah dengan jawaban sangat setuju sebanyak 35 orang atau $13,7 \%$.

Sebelum dilakukan pengolahan data maka seluruh jawaban yang diberikan oleh responden di uji dengan uji validitas dan uji realibilitas yang diujicobakan pada responden. Uji validitas dilakukan dengan menggunakan korelasi product moment. Hasil uji validitas variabel dengan menampilkan seluruh item pernyataan yang bersangkutan mengenai sikap mahasiswa terhadap Perguruan Tinggi IBIK diukur dengan konsep kepercayaan (bi). Hasil yang didapatkan yaitu nilai rhitung>rtabel. Dengan demikian seluruh item pernyataan Mengenai sikap atas pelayanan diukur dengan Konsep kepercayaan (bi) dinyatakan valid.

Berdasarkan hasil uji reliabilitas variabel Kepercayaan atau belief (bi) adalah 0,7751 . Hal ini menunjukkan bahwa instrumen dalam mengukur variabel Kepercayaan (bi) adalah reliabel (handal) dan masuk dalam kategori tinggi. Demikian halnya dengan reliabilitas variabel evaluasi (ei) adalah 0,8098. Hal ini menunjukkan bahwa instrumen dalam mengukur variabel evaluasi (ei) adalah reliabel (handal) dan masuk dalam kategori sangat tinggi. Maka secara umum, instrumen yang dibangun adalah handal untuk memperoleh data penelitian ini.

\section{Performance dan Kepercayaan (bi)}

Berdasarkan hasil penelitian, nilai tingkat kepercayaan responden mengenai Perguruan Tinggi di Kota Bogor dengan nilai 3.841 berada di posisi 4 sehingga dapat dinyatakan berada pada kategori baik. 
Jika dilihat lebih rinci, maka terlihat bahwa faktor lokasi berada pada urutan tertinggi, yang menunjukkan bahwa lokasi menjadi concern utama mahasiswa dalam mempilih suatu perguruan tinggi di Kota Bogor. Responden melihat bahwa lokasi PT termasuk dalam kategori Sangat Baik.

Tabel 4. Tingkat Kinerja (Performance) Atribut Perguruan Tinggi berdasarkan Konsep Belief (bi)

\begin{tabular}{lcl}
\hline Atribut & Performance & \multicolumn{1}{c}{ Makna } \\
\hline Lokasi & 4.254 & Sangat Baik \\
Kualitas akreditasi & 4.176 & Baik \\
Mudah bekerja & 4.113 & Baik \\
Pelayanan & 4.074 & Baik \\
Fasilitas, & 4.023 & Baik \\
Kualitas dosen, & 3.887 & Baik \\
Biaya kuliah, & 3.867 & Baik \\
Suasana kampus & 3.609 & Baik \\
Faktor teman/keluarga & 3.355 & Baik \\
Beasiswa & 3.047 & Cukup Baik \\
\hline Rata-rata (in general) & 3.841 & Baik \\
\hline
\end{tabular}

Disamping itu, terdapat 8 Atribut yang tergolong baik, yang secara berturut turut adalah sebagai berikut : kualitas akreditasi, mudah bekerja, pelayanan fasilitas, kualitas dosen, biaya kuliah, suasana kampus, dan faktor teman/keluarga.

\section{Importance dan Evaluasi (ei)}

Tabel 5. Tingkat Kepentingan (Importance) Atribut IBI Kesatuan berdasarkan Konsep Evaluasi (ei)

\begin{tabular}{lcl}
\hline Atribut & Importantance & \multicolumn{1}{c}{ Makna } \\
\hline Mudah bekerja & 4.316 & Sangat Penting \\
Kualitas Akreditasi & 4.313 & Sangat Penting \\
Lokasi & 4.199 & Penting \\
Fasilitas, & 4.164 & Penting \\
Pelayanan & 4.160 & Penting \\
Kualitas Dosen, & 4.125 & Penting \\
Suasana kampus & 4.035 & Penting \\
Biaya Kuliah, & 4.012 & Penting \\
Beasiswa & 3.453 & Penting \\
Faktor Teman/Keluarga & 3.309 & Cukup Penting \\
\hline Rata-rata (in General) & 4.009 & Penting
\end{tabular}

Berdasarkan hasil evaluasi responden, yang menggambarkan tingkat kepentingan responden dalam memilih kampus IBI Kesatuan diperoleh rata-rata score 4.009 berada di posisi 4 berada pada kategori baik.

Terdapat dua atribut yang paling tinggi dan masuk dalam kategori sangat penting, yakni Mudah bekerja (4.316) dan Kualitas Akreditasi (4.313). Para mahasiswa berhadap,

JAS-PT

JURNAL ANALISIS SISTEM PENDIDIKAN TINGGI ISSN $2580-5339$ eISSN $2620-5718$ Volume 5

Nomor 1

JULI 2021

Hal 39 - 48 bahwa setelah lulus akan mudah bekerja. Hal ini berhubungan dengan brand image dan citra yang dibangun oleh Bagian Marketing IBI Kesatuan, bahwa IBI Kesatuan bisa memenuhi harapan mahasiswa tersebut. Dan atribut kedua adalah Akreditasi, yang mencerminkan kualitas IBI Kesatuan. Faktor kualitas merupakan faktor yang penting dan para mahasiswa meyakini bahwa mereka tidak salah dalam mengambil keputusan kuliah ke IBI Kesatuan. 
Disamping itu, terdapat 7 Atribut yang tergolong penting, yang secara berturut turut adalah sebagai berikut : Lokasi, Fasilitas, Pelayanan, Kualitas Dosen, Suasana kampus, Biaya Kuliah, Beasiswa.

\section{Sikap Mahasiswa dalam Memilih IBI Kesatuan}

Sikap mahasiswa dalam memilih IBI Kesatuan adalah gabungan dari kedua variabel di atas, yakni faktor kepercayaan dan faktor evaluasi. Berdasarkan hasil penelitian, dipeorleh Nilai Sikap (A0) sebagai berikut.

Tabel 6 Nilai Sikap Mahasiswa Pada Pemilihan Kampus IBI Kesatuan

\begin{tabular}{|c|c|c|}
\hline$\sum(b i) \cdot(e i)$ & Nilai Sikap Ao & Interpretasi \\
\hline$|\mathrm{B}|$ Kesatuan & 159.94 & Baik \\
\hline
\end{tabular}

Sumber: Data diolah berdasarkan kuisioner tahun 2020

Hasil penelitian tersebut menunjukkan bahwa sikap mahasiswa dalam mengambil keputusan memilih IBI Kesatuan adalah dalam kategori baik.

\section{Analisis Gap (Tingkat Kesenjangan)}

Jika dikaji lebih dalam, hasil jawaban responden atas kepercayaan dan evaluasi di atas, menghasilkan score 159.94 atau kategri baik. Temuan ini mengungkapkan bahwa IBI Kesatuan masih bisa meningkatkan score kinerjanya pada masa mendatang. Karena angka score ini jika dipersentasekan ke nilai maksimum sebesar 250, maka capaian saat ini baru mencapai $63.98 \%$. Artinya gap untuk posisi maksimum masih cukup jauh, yakni sekiatr $36 \%$. Angka ini menggambarkan kesenjangan atau gap ke posisi terbaik.

Jika dilakukan secara bertahap, maka untuk mencapai score $80 \%$ (batas bawah sangat baik), maka besarnya gap yang perlu diperjuangkan adalah $16.02 \%$. Besarnya angka kesenjangan (gap) ini bertujuan memotivasi IBI Kesatuan dalam meningkatkan kinerjanya pada masa mendatang.

\section{Matriks Performance dan Importance IBI Kesatuan}

Sejalan dengan analisis di atas mengenai variabel kinerja (performance) dan Kepentingan (importance), maka score masing masing menunjukkan titik kordinat yang secara visual disajikan pada gambar di bawah ini.

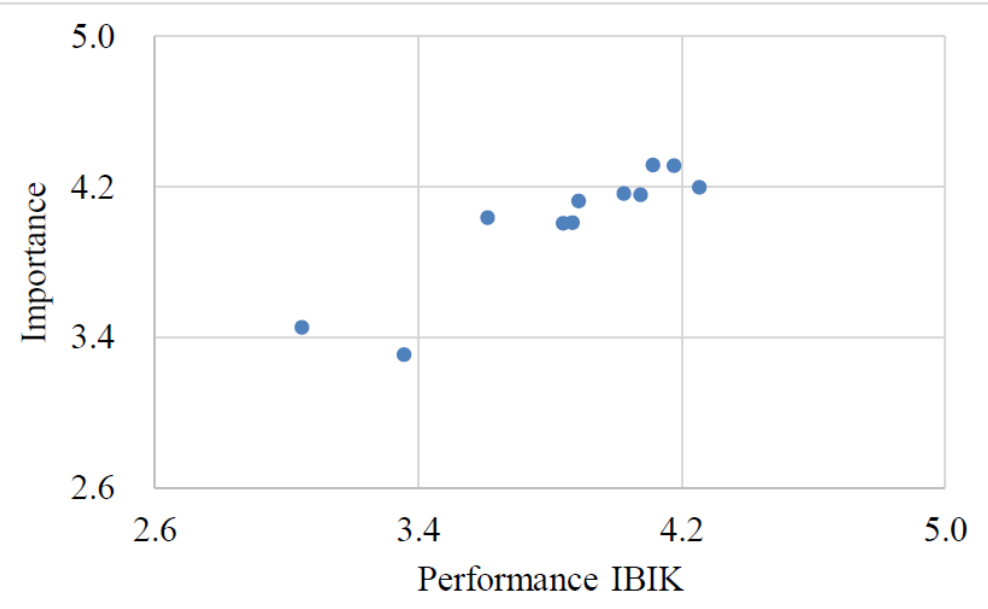

\section{Gambar 1. Grafik Performance IBI Kesatuan dan Importance Atribut}

Berdasarkan koordinat grfaik di atas, maka dapat dilihat masing masing score performance berada pada range cukup baik, baik dan sangat baik, demikian halnya dengan tingkat kepentingan (importance) berada pada range cukup penting, penting dan

JAS-PT

JURNAL ANALISIS SISTEM PENDIDIKAN TINGG ISSN $2580-5339$ elSSN $2620-5718$ Volume 5 Nomor 1 JULI 2021 Hal 39 - 48 
sangat penting. Koordinat ke-10 Atribut penelitian membentuk area kuadran kuadran, yang dapat disajikan pada tabel di bawah ini

Tabel 7. Score Kepentingan dan Kinerja Kampus IBI Kesatuan

\begin{tabular}{clll}
\hline No & \multicolumn{1}{c}{ Importance } & \multicolumn{1}{c}{ Performance } & \multicolumn{1}{c}{ Atribut } \\
\hline 1 & Sangat Penting & Baik & $\begin{array}{l}\text { Mudah bekerja } \\
\text { Kualitas Akreditasi }\end{array}$ \\
\hline 2 & Penting & Sangat Baik & Lokasi \\
\hline 3 & Penting & Baik & $\begin{array}{l}\text { Fasilitas, Pelayanan } \\
\text { Kualitas Dosen, } \\
\end{array}$ \\
& & Suasana kampus \\
& & Biaya Kuliah, \\
\hline 4 & Penting & Sedang & Beasiswa \\
\hline 5 & Cukup Penting & Sedang & Faktor Teman/Keluarga \\
\hline
\end{tabular}

Hasil grafik dan Tabel 7 di atas, diperoleh bahwa ke-10 atribut menyebar dalam 5 kelompok.

\section{SIMPULAN DAN SARAN}

Kesimpulan dari penelitian ini mengenai sikap mahasiswa terhadap pemilihan Perguruan Tinggi dengan metode fishbein adalah sebagai berikut:

1. Berdasarkan nilai kepercayaan sikap mahasiswa terhadap pemilihan perguruan tinggi di Kota Bogor diperoleh rata-rata score dengan nilai 3.841, dan berada pada kategori baik. Atribut lokasi menjadi concern utama mahasiswa dalam mempilih suatu perguruan tinggi di Kota Bogor. Akreditasi merupakan atribut penting bagi mahasiswa dalam memilih sebuah perguruan tinggi, diikuti kemudahan bekerja.

2. Berdasarkan nilai evaluasi sikap mahasiswa terhadap perguruan tinggi IBI Kesatuan. Secara keseluruhan dari evaluasi pada atribut-atribut perguruan tinggi, menggambarkan tingkat kepentingan responden dalam memilih kampus $|\mathrm{B}|$ Kesatuan diperoleh rata-rata score 4.009 berada pada kategori baik. Terdapat dua atribut yang paling tinggi dan masuk dalam kategori sangat penting, yakni Mudah bekerja (4.316) dan Kualitas Akreditasi (4.313), dan Akreditasi yang mencerminkan kualitas IBI Kesatuan. Faktor kualitas merupakan faktor yang penting dan para mahasiswa meyakini bahwa mereka tidak salah dalam mengambil keputusan kuliah ke IBI Kesatuan.

3. Nilai sikap dengan model Fishbein dalam pemilihan Perguruan Tinggi IBI Kesatuan didapat score sikap sebesar 159,94 berada pada interval "baik".

\section{DAFTAR PUSTAKA}

Ali, Hapzi dan Azizah. (2009). Analisis Faktor-Faktor Yang Mempengaruhi Motivasi Konsumen Dalam Memutuskan Pembelian Jasa (Studi Kasus: PO. Imi Fatwa Sakti Travel Jambi). Jurnal IImiah Universitas Batanghari. Universitas Batanghari. Jambi.

JAS-PT

JURNAL ANALISIS SISTEM PENDIDIKAN TINGGI ISSN $2580-5339$ eISSN $2620-5718$

Volume 5

Nomor 1

JULI 2021

Hal $39-48$

DOSEN INDONESIA SEMESTA
Amyar, F., Hidayah, N. N., Lowe, A., \& Woods, M. (2019). Investigating the backstage of audit engagements: the paradox of team diversity. Accounting, Auditing \& Accountability Journal.

Astrini, D. (2020). Pendampingan Pemberdayaan Ibu-lbu Kelompok Wanita Tani Dalam Pemanfaatan Daun Sirih Sebagai Bahan Dasar Pembuatan Hand Sanitizer. Jurnal Abdimas, 4(2), 91-100. 
Cannon, Joseph P. \&Perreault, William, D et al. (2009). Basic Marketing, a Marketing Strategy Planning Approach. Boston: McGraw Hill

Cahyani, N. (2020). Peningkatan Kapabilitas UMKM Binaan Rumah Kreatif Bogor Dalam Pemasaran Produk Dan Jasa. Jurnal Abdimas, 4(1), 12-20.

Cooper, Donald R dan Pamela S. Schindler. (2008). Business research Methods (Tenth Edition). Singapore : Mc Graw Hill.

Gendalasari, G. G. (2020). A Market-Based analysis On Small and A Medium Busines Strategies in Bogor's Footwear Industry. Riset, 2(1), 153-166.

Gendalasari, G. G., \& Triandi, T. (2018, December). Strategy For Improving Performance and Competitive Advantages of Export-Based Shoe Msme in Bogor in The Free Trade Competition. In International Conference On Accounting And Management Science 2018 (pp. 315-321).

Harish, Aghnia Ghassani dan wardhana, Aditya. (2016). Analisis Faktor-Faktor Pembentuk Preferensi Konsumen Go-Jek Di Kota Jakarta. Jurnal Management 3(2).Universitas Telkom. Bandung.

Hermawan, Herry. (2017). Sikap Konsumen terhadap Belanja Online. Wacana 16(1). Universitas Prof. Dr. Moestopo (Beragama). Jakarta.

Kotler, Philip dan Gary Armstrong. (2008). Prinsip-prinsip Pemasaran (Jilid 1, Edisi 12). Jakarta: Erlangga

Kristianto, Paulus Lilik. (2011). Psikologi Pemasaran : Integrasi IImu Psikologi dalam Kegiatan Pemasaran. Jakarta : CAPS .

Lupioadi, Rambat dan Ridho. (2015). Praktikum Metode Riset Bisnis. Salemba Empat. Jakarta.

Malhotra, Naresh K. (2009). Riset Pemasaran : Pendekatan Terapan (Jilid 1, Edisi 4). Jakarta: PT Macanan Jaya Cemerlang.

Mulyana, M. (2012). Consumer Behaviour: Sukses Dengan Memahami Konsumen.

Mulyana, M., \& Puspitasari, R. (2014). Model Struktural Minat Berwirausaha Siswa SMK Di Kota Bogor. SNIT 2014, 1(1), 83-91.

Muktiadji, N., \& Hendrian, G. (2018). Pelatihan Motivasi Usaha Bagi UMKM Kota Bogor. Jurnal Abdimas, 2(1), 078-082.

Nitisusastro, H. Mulyadi. (2012). Perilaku Konsumen dalam Perspektif Kewirausahaan. Bandung: Alfabeta

Nofiawaty. (2013). Analisis Sikap Multi Atribut Fishbein terhadap produk mobil nissan xTrail pada PT. Nissan Istana Palembang. Jurnal Orasi Bisnis Edisi ke-X. Universitas Sriwijaya. Palembang.

Nugraha, A. A., Purba, J. H. V., \& Sastra, H. (2019). Analisis Kebijakan Pendanaan Jangka Panjang (Studi Kasus Pada Perusahaan Pt Sat Nusa Persada Tbk). Jurnal IImiah Manajemen Kesatuan, 7(1), 138-144.

Puspita, W., Nugrahani, R. (2014). Analisis Sikap Multi Atribut Fishbein mengenai Atribut Obat Herbal Merek Tolak Angin Sido Muncul Di Kota Bandung. Jurnal Sosio teknologi Volume 13, Nomor 1. Universitas Telkom. Bandung.

Sangadji, Etta Mamang dan Sopiah. (2013). Perilaku Konsumen. Andi. Yogyakarta.

Sanusi, Anwar. (2014. Metodologi Penelitian Bisnis. Salemba Empat. Jakarta.

Sarwono, Jonathan \& Tutty Martadiredja. (2008). Riset Bisnis untuk Pengambilan Keputusan. Yogyakarta: Andi

Schiffman, Leon \& Kanuk, Leslie Lazar. (2008). Consumer Behaviour 7th Edition

Setiadi, Nugroho J., (2008) .Perilaku Konsumen : Konsep dan Implikasi untuk Strategi dan Penelitian Pemasaran, Edisi Pertama. Jakarta : Kencana Prenada Media Group.

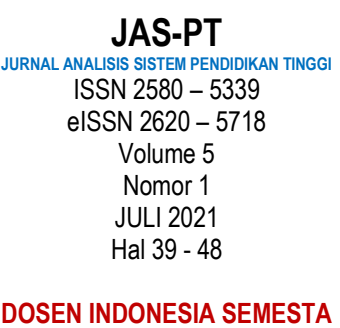


Simamora, Bilson. (2004). Panduan Riset Perilaku Konsumen. Gramedia Pustaka Utama. Jakarta.

Sudradjat, S., Muktiadji, N., Gendalasari, G. G., \& Hendrian, G. (2016). Pengaruh Motivasi Belajar Dan Status Ekonomi Orang Tua Terhadap Minat Studi Lanjut Siswa/Siswi Sma Dan Smk Di Bogor Pada Bidang Ekonomi Dan Manajemen. Jurnal IImiah Manajemen Kesatuan, 4(3), 159-173.

Sugiyono. (2014). Metode Penelitian Bisnis. Alfabeta. Bandung.

Sumarwan, Ujang. (2011). Perilaku Konsumen Teori dan Penerapannya Dalam Pemasaran, Edisi 2. Bogor: Ghalia Indonesia

Sunyoto, Danang. (2012). Konsep Dasar Riset Pemasaran \& Perilaku Konsumen. Jakarta: PT Buku Seru

Umar, Husein. (2005). Riset Pemasaran \& Perilaku Konsumen. Jakarta : PT SUN 